\title{
Antibiofilm properties exhibited by the prickly pear (Opuntia ficus-indica) seed oil
}

\author{
Filomena Nazzaro ${ }^{*}$, Florinda Fratianni ${ }^{1}$, Antonio d'Acierno ${ }^{1}$, Lucia Caputo ${ }^{2}$, Vincenzo De Feo ${ }^{2}$ \\ and Raffaele Coppola ${ }^{3}$, \\ ${ }^{1}$ Institute of Food Science, CNR-ISA, Via Roma 64, 83100, Avellino, Italy; fratianniòisa.cnr.it (FF); \\ dacierno.a@isa.cnr.it (A.d.A.) \\ ${ }^{2}$ DiFARMA, University of Salerno, via Giovanni Paolo II, Fisciano (SA) Italy; caputo@unisa.it (LC); \\ defeo@unisa.it (VDF) \\ ${ }^{3}$ DiAAA, University of Molise, Via de Sanctis snc, 86100, Campobasso, Italy; e-mail@e-mail.com Affiliation 2; \\ coppola@unimol.it (RC) \\ * Correspondence: filomena.nazzaro@isa.cnr.it (FN); Tel.: (+390825299102 (FN) \\ + Presented at the 1st International Electronic Conference on Microbiology, 02-30 November 2020; Available \\ online: https://ecm2020.sciforum.net/
}

Published: 02 November 2020

\begin{abstract}
Prickly pear Opuntia ficus-indica (L.) Mill.,1768) is a succulent plant world widely diffused The oil obtained from its seeds has antimicrobial and antioxidant properties. We evaluated the antibiofilm of the oil and its capacity to block the metabolic changes taking place in the microbial cells included in the biofilm. The oil was capable to inhibit at 38.75\% the biofilm of Escherichia coli, Pseudomonas aeruginosa and Pectobacterium carotovorum (38.75 \%, 71.84\% and $63.06 \%$ inhibition, respectively). The metabolic activity of the microbial cells within the biofilm was also strongly inhibited. The action of the prickly pear seeds oil was effective also in blocking at $64.97 \%$ the metabolism of Listeria monocytogenes cells.
\end{abstract}

Keywords: Opuntia ficus-indica; seeds oil; Biofilm; Escherichia coli; Pseudomonas aeruginosa; Pectobacterium carotovorum;

\section{Introduction}

Prickly or cactus pear [Opuntia ficus-indica (L.) Mill., 1768] is a succulent plant belonging to the Cactaceae family, native to Central America but now diffused both in the Mediterranean area (mainly Sicily, Calabria, Puglia, Sardinia and Malta) and in the temperate areas of America, Africa, Asia and Oceania. It is a drought-tolerant crop and needs of low agronomic requirements and high water use efficiency. Generally, fruits are used for human consumption and cladodes (called pad) are consumed as animal feed. Fruit is an oval-shaped berry with an average weight of 100-200 g, constituted mainly by juicy pulp [1]. Seeds contribute from 10 to $15 \%$ to the pulp weight. Oil obtained from the seed represents $7-15 \%$ of the whole seed weight [2]. Seeds also have a high content of oil (98.8 g/kg) [3], characterized by high levels of linoleic and oleic acids and other components as phenols, all of with benefit on human health [4-8]. The health-promoting properties of prickly pear fruit is highly appealing, also for the development of nutraceutical and functional foods, as well as for the emphasis that consumers give toward the search of new products or components with high benefit.

Cactus pear contains several bioactive compounds exhibiting high antioxidant and antimicrobial activity [9].

The antimicrobial activity of the cactus pear seed oil has been demonstrated vs different pathogens, such as Escherichia coli, Staphylococcus aureus and Pseudomonas aeruginosa [10]. The oil 
resulted useful also as preserving agent to improve the shelf life of fresh food, such as sliced beef, meliorating concurrently the quality of the product and safeguarding it from a microbiological point of view [11]. The extract of cactus pear cladodes showed a noticeable activity in inhibiting the biofilm formation of St. aureus [12]. Aim of our work was to evaluate the capacity of the prickly pear seeds oil in inhibiting the formation of biofilm of different pathogens and in blocking the metabolic changes taking place in the microbial cells included in the biofilm.

\section{Material and methods}

Organic prickly pear (Opuntia ficus-indica L.) seed oil, obtained through cold pressure, was purchased from the company Bionoble Cosmétiques BIO (Paris, France). The bacterial culture medium, PBS, DMSO, tetracycline, ciprofloxacin, and MTT were supplied by Sigma (Milano, Italy).

\subsection{Microorganisms and Culture Conditions}

Listeria monocytogenes ATCC 7644, EHEC, Escherichia coli DSM 8579, Pseudomonas aeruginosa DSM 50071, and the phytopathogen Pectobacterium carovotorum DSM 102074 were used as test bacterial strains. They were previously stored the strains at $-30{ }^{\circ} \mathrm{C}$ in sterile Luria Bertani (LB) broth (Sigma) supplemented with $20 \%$ sterile glycerol (Sigma). Bacteria were thawed and added (inoculum $2 \%$ ) to LB broth. E. coli, L. monocytogenes and P. aeruginosa were grown for $18 \mathrm{~h}$ at $37^{\circ} \mathrm{C}$ and $80 \mathrm{rpm}$ (Corning LSE, Pisa, Italy). P. carotovorum was grown at $28^{\circ} \mathrm{C}$ and $80 \mathrm{rpm}$. Fresh cultures were used as inoculum ( $2 \%$ final concentration) and grown in the conditions above described.

\subsection{Minimal Inhibitory Concentration (MIC)}

The MIC values were calculated using the resazurin microtiter-plate assay [13]. Multiwell plates were prepared in triplicate and incubated at $37^{\circ} \mathrm{C}$ for $24 \mathrm{~h}$. The lowest concentration at which a color change occurred (from dark purple to colorless) revealed the MIC value.

\subsection{Biofilm Inhibitory Activity}

The effect of the prickly pear seeds oil on bacterial ability to form biofilm was assessed according to the method of O'Toole and Kolter [14] in flat-bottomed 96-well microtiter plates, using volumes of the oil (previously dissolved in sterile DMSO) ranging from 1 to $8 \mu \mathrm{l} / \mathrm{mL}$. The overnight bacterial cultures were adjusted to $0.5 \mathrm{McF}$ arland with fresh culture broth. Then, $10 \mu \mathrm{L}$ of the diluted cultures was distributed in each well, and different volumes of the oil and sterile Luria-Bertani broth were added, to reach a final volume of $250 \mu \mathrm{L} /$ well. Microplates were completely covered with parafilm tape, to avoid the evaporation of samples with relative loss of volume and incubated for $48 \mathrm{~h}$ at different temperatures (depending on the strain). Planktonic cells were removed and the attached cells were gently washed twice with sterile physiological saline. After that, $200 \mu \mathrm{L}$ of methanol was added to each well, retaining it for $15 \mathrm{~min}$ to fix the sessile cells. Methanol was then discarded, and each plate was left until complete dryness of samples. The staining of the adhered cells was obtained by adding $200 \mu \mathrm{L}$ of $2 \% \mathrm{w} / \mathrm{v}$ crystal violet solution to each well that was left for $20 \mathrm{~min}$. Wells were gently washed with sterile physiological solution and left to dry. Two hundred microliters of glacial acetic acid $20 \% \mathrm{w} / \mathrm{vwere}$ added to allow the release of the bound dye. The absorbance was measured at $\mathrm{OD}=540 \mathrm{~nm}$ (Varian Cary Spectrophotometer model 50 MPR, Cernusco sul Naviglio, Italy). The percent value of biofilm inhibition was calculated with respect to control (cells grown without the presence of the EOs). The average results from triplicate tests were taken for reproducibility.

\subsection{Metabolic Activity of Biofilm Cells}

The effect of different volumes of prickly pear seeds oil, ranging from 1 to $8 \mu \mathrm{l} / \mathrm{mL}$ on the metabolic activity of biofilm cells, was evaluated through the MTT colorimetric method [15-16] using 96-well microtiter plates. The overnight bacterial cultures were adjusted to $0.5 \mathrm{McF}$ arland and treated as described in Section "Biofilm Inhibitory Activity." After $48 \mathrm{~h}$ incubation, bacterial suspension was 
removed and $150 \mu \mathrm{L}$ of sterile PBS and $30 \mu \mathrm{L}$ of $0.3 \%$ MTT (Sigma, Milan, Italy) were added, keeping microplates at $37^{\circ} \mathrm{C}$. After $2 \mathrm{~h}$, the MTT solution was removed, two washing steps were performed gently with $200 \mu \mathrm{L}$ of sterile physiological solution, and $200 \mu \mathrm{L}$ of DMSO was added to allow the dissolution of the formazan crystals, which were measured at $\mathrm{OD}=570 \mathrm{~nm}$ (Varian). Triplicate tests were carried out and the average results were taken for reproducibility.

\section{Results and Discussion}

Based on the minimal inhibitory activity exhibited by the prickly pear seeds oil (Table 1), we provided to evaluate the potential effect that different volumes of this oil could have on the formation of biofilm of some pathogenic bacteria and assessed if the oil could exhibit some inhibitory effect also on the metabolism of the cells included in the biofilm.

Table 1. Minimal inhibitory concentration ( $\mathrm{L} / \mathrm{mL}$ ) of the prickly pear seeds oil evaluated through the resazurin test, as reported in the Materials and Methods.

\begin{tabular}{cc}
\hline Table $\mathbf{1}$ & MIC $(\mathrm{mL} / \mathrm{mL})$ \\
\hline E. coli & $10.0( \pm 1.0)$ \\
\hline L. monocytogenes & $15.0( \pm 2.0)$ \\
\hline P. carotovorum & $12.0( \pm 1.0)$ \\
\hline Ps. aeruginosa & $11.0( \pm 1.0)$ \\
\hline
\end{tabular}

The data acquired showed that the O. ficus-indica seeds oil has an interesting capability to inhibit the growth of different pathogens, confirming previous studies, which demonstrated the effectiveness of this oil in inhibiting the growth of different Gram-positive and Gram-negative negative pathogens [10,17-18]. To our knowledge, this is the first time that the possible capability of the oil to inhibit the formation of biofilms by pathogenic microorganisms was evaluated. Therefore, it is also the first time that the effect of the oil on the metabolism of microbial cells trapped inside the biofilm has been studied. Results are shown in Tables 2 and 3, respectively.

E. coli and P. carotovorum were sensitive to the action of the oil even when we tested one $\quad \mathrm{L} / \mathrm{mL}$, which caused an inhibition of the biofilm of $36.77 \%$ and $43.33 \%$, respectively (Table 2).

Table 2. Inhibitory action of O. ficus-indica seeds oil on the formation of biofilm. Results are reported as percent of inhibition respect to the control $(\%=0)$. They are the mean $( \pm S D)$ of three experiments.

\begin{tabular}{|c|c|c|c|c|}
\hline Table 2 & $1 \quad 1 / \mathrm{ml}$ & $2 \quad 1 / \mathrm{ml}$ & $4 \quad 1 / \mathrm{ml}$ & $1 / \mathrm{ml}$ \\
\hline E.coli & $36.77(3.31)$ & $62.56(2.79)$ & $68.03(1.90)$ & $75.79(1.98)$ \\
\hline L.monocytogenes & $0(0)$ & $16.27(1.52)$ & $24.66(1.67)$ & $31.18(1.94)$ \\
\hline P. carotovorum & $43.33(0.57)$ & $31.01(4.3)$ & $56.99(1.67)$ & $63.06(1.13)$ \\
\hline P.aeruginosa & $0(0)$ & $41.34(1.13)$ & $44.26(0.35)$ & $73.84(0.9)$ \\
\hline
\end{tabular}

Such action was much more incisive when we used eight L/mL: in this case, we detected percentages of biofilm inhibition of $63.06 \%$ (P. carotovorum) and $75.79 \%$ (E. coli). Ps. aeruginosa, which also proved to be resistant to the action of one $\quad 1 / \mathrm{ml}$ of the oil, instead showed percentages of biofilm inhibition that reached $73.84 \%$ using eight $\mathrm{L} / \mathrm{ml}$ of the oil.

The metabolic activity of the microbial cells present within the biofilm was also strongly inhibited (Table 3) and, when the oil was tested against $P$. carotovorum, the microbial cell metabolism was completely inhibited.

Table 3. Metabolic activity exhibited by the cells present within the bacterial biofilms in the presence of different volumes of $O$. ficus indica seeds oil. Results are reported as percent of inhibition respect to the control $(\%=0)$. They are the mean $( \pm S D)$ of three experiments. 


\begin{tabular}{|c|c|c|c|c|}
\hline Table 3. & $1 \mathrm{ml} / \mathrm{ml}$ & $2 \mathrm{ml} / \mathrm{ml}$ & $4 \mathrm{ml} / \mathrm{ml}$ & $8 \mathrm{ml} / \mathrm{ml}$ \\
\hline E. coli & $81.98(1.13)$ & $84.45(0.57)$ & $91.16(0.33)$ & $96.26(0.33)$ \\
\hline L.monocytogenes & $0(0)$ & $38.83(1.52)$ & $61.23(1.67)$ & $64.97(1.13)$ \\
\hline P. carotovorum & $22.21(0.57)$ & $76.06(0.57)$ & $95.25(0.33)$ & $98.35(0.33)$ \\
\hline P. aeruginosa & $0(0)$ & $31.41(0.57)$ & $53.42(1.13)$ & $64.33(1.90)$ \\
\hline
\end{tabular}

A similar behavior was exhibited by E. coli, which cell metabolism was almost completely inhibited (96.26\%) using eight $\mathrm{L} / \mathrm{mL}$ of the oil. The action of the prickly pear seeds oil was effective also in blocking at $64.97 \%$ the metabolism of L. monocytogenes cells, which therefore had conversely demonstrated to be more resistant compared to the other bacteria ( $31 \%$ of biofilm inhibition when we tested the highest volume of the O. ficus-indica seeds oil). This could suggest that, conversely to a general higher resistance exhibited by the Gram-negative bacteria to biocides [19], the Gram-positive strain used in these experiments, that is L. monocytogenes, could be slightly more resistant, for the same volume of oil used, during the biofilm formation phase, but not from a metabolic point of view. The activity exhibited by the oil against the phytopathogen $P$. carotovorum makes it a candidate to treat and prevent bacterial infections in crops for instance using new species-specific technologies, such as the encapsulation of the oil in mesoporous silica nanoparticles [20]. Data from the present study indicates an interesting applicative versatility of this oil, with potentialities for food, agriculture and health purposes.

Author Contributions: FN: VDF, RC: conceptualization. FN, AdA, FF and LC: investigations. All authors contributed to writing and revising the manuscript. Funding: This research received no external funding.

Conflicts of Interest: The authors declare no conflict of interest.

\section{References}

1. Pimienta-Barrios, E.; Barbera, G.; Inglese, P. Cactus pear (Opuntia spp. Cactaceae) International Network: An effort for productivity and environmental conservation for arid and semiarid lands. Cactus Succulent J. 1993, 65, 225-229.

2. Stintzing, F. C.; Schieber, A.; Carle, R. Cactus pear, a promising component of functional food. Gemüse und Kartoffelverarbeitung 2000, 85, 40-47.

3. Ramadan, M. F.; Mörsel, J.-T. Oil cactus pear (Opuntia ficus-indica L.). Food Chem 2003, 82, 339-345.

4. Bhatt, M. R.; Nagar, P. S. Evaluation of physicochemical property and fatty acid composition of Opuntia elatior seed oil. J. Prof. Ass. Cactus Develop. 2013, 15, 13-19.

5. El-Mostafa, K.; Kharrassi, Y.; Badreddine A.; Andreoletti, P.; Vamecq, J.; El Kebbaj, M. S.; Latruffe, N.; Lizard, G.; Nasser, B.; Charkaoui-Malki, M. Nopal Cactus (Opuntia ficus-indica) as a source of bioactive compounds for nutrition, health and disease. Molecules 2014 19, 14879-14901.

6. Ghazi, Z.; Ramdai, M.; Fauconnier, M. L.; El Mahi, B.; Cheikh, R. Fatty acids, sterols and Vitamin E composition of seed oil of Opuntia ficus indica and Opuntia dilenii from Morocco. J. Mat. Environ. Sci. 2013, 4, 967-972.

7. Labuschagne, M.T.; Hugo, A. Oil content and fatty acid composition of cactus pear seed compared with cotton and grape seed. J. Food. Biochem 2010, 34, 93-100.

8. Mensink, R.P.; Katan, M.B. Effect of dietary trans fatty acids on high-density and low-density lipoprotein cholesterol levels in healthy subjects. N. Engl. J. Med. 1992 323, 439-445.

9. Kaur, M.; Kaur, A.; Sharma, R. Pharmacological actions of Opuntia ficus indica: a review. J. Appl. Pharm. Sci. 2012, 2, 15-18.

10. Ortega, M.D.L.A.O; Cruz-Cansino, N.D.S.; Alanís-García, E.; Delgado-Olivares, L.; Ariza-Ortega, J.A.; Ramírez-Moreno, E.; Manríquez-Torres., J. J. Optimization of ultrasound extraction of cactus pear (Opuntia ficus indica) seed oil based on antioxidant activity and evaluation of its antimicrobial activity. J. Food Quality, 2017, 9315360.

11. Palmeri, R.; Parafati, L.; Restuccia, C.; Fallico, B. Application of prickly pear fruit extract to improve domestic shelf life, quality and microbial safety of sliced beef. Food Chem. Toxicol. 2018, 118, 355-360. 
12. Blando, F.; Russo, R.; Negro, C.; De Bellis, L.; Frassinetti, S. Polyphenolic extracts from cladodes of Opuntia ficus-indica (L.) Mill. to inhibit the growth of some enterobacteria and the biofilm formation by Staphylococcus aureus. Antioxidants 2019, 8, 117; doi: 10.3390/antiox8050117.

13. Sarker, S. D.; Nahar, L.; Kumarasamy, Y. Microtitre plate-based antibacterial assay incorporating resazurin as an indicator of cell growth, and its application in the in vitro antibacterial screening of phytochemicals. Methods 2007, 42, 321-324.

14. O'Toole, G. A.; Kolter, R. Flagellar and twitching motility are necessary for Pseudomonas aeruginosa biofilm development. Mol. Microbiol. 1998, 30, 295-304.

15. Kairo, S. K.; Bedwell, J.; Tyler, P. C.; Carter, A.; Corbel, M. J. Development of a tetrazolium salt assay for rapid determination of viability of BCG vaccines. Vaccine 1999, 17, 2423-2428.

16. Fratianni, F.; Cozzolino, A.; De Feo, V.; Coppola, R.; Ombra, M. N.; Nazzaro, F. Polyphenols, antioxidant, antibacterial, and biofilm inhibitory activities of peel and pulp of Citrus medica L., Citrus bergamia, and Citrus medica cv. Salò Cultivated in Southern Italy. Molecules 2019, 24, 4577.

17. R'bia, O.; Chkioua, C.; Hellal, R.; Herchi, W.; Aschi Smiti, S. Antioxidant and antibacterial activities of Opuntia ficus indica seed oil fractions and their bioactive compounds identification. Turkish J. Biochem .2017, 42, 481-491.

18. Ramírez-Moreno, E.; Cariño-Cortés, R.; del Socorro Cruz-Cansino, N.; Delgado-Olivares, L.; Ariza-Ortega, J.A.; Montañez-Izquierdo, V. Y.; Hernández-Herrero, M. M.; Filardo-Kerstupp, T. Antioxidant and Antimicrobial Properties of Cactus Pear (Opuntia) Seed Oils. J. Food Quality, 2017, 3075907.

19. Nazzaro, F.; Fratianni, F.; De Martino, L.; Coppola, R.; De Feo. V. Effect of essential oils on pathogenic bacteria. Pharmaceuticals 2013, 6, 1451-1474.

20. Cadena, M. B.; Preston, G. M.; Van der Hoorn, R. A. L.; Townley, H. E.; Thompson, I. P. Species-specific antimicrobial activity of essential oils and enhancement by encapsulation in mesoporous silica nanoparticles. Ind. Crops Prod. 2018, 122, 582-590.

Publisher's Note: MDPI stays neutral with regard to jurisdictional claims in published maps and institutional affiliations.

(C) 2020 by the authors. Submitted for possible open access publication under the terms and conditions of the Creative Commons Attribution (CC BY) license (http://creativecommons.org/licenses/by/4.0/). 